\title{
ENHANCING THERMAL ENVIRONMENT QUALITY WITH VOIDS AND INDOOR GARDENS AS A PASSIVE DESIGN STRATEGY TOWARDS SUSTAINABLE AND HEALTHY LIVING
}

\author{
Anggana Fitri Satwikasari ${ }^{1 *}$, Luqmanul Hakim $^{1}$, Lutfi Prayogi $^{1}$ \\ ${ }^{1}$ Department of Architecture Universitas Muhammadiyah Jakarta, \\ Jl.Cempaka Putih 27 Jakarta Pusat, 10510, Indonesia
}

(Received: July 2018 / Revised: August 2018 / Accepted: December 2018)

\begin{abstract}
Subjective evaluation plays an important role in assessing indoor thermal quality (ASHRAE55). This study assesses the physical and pyschological aspects of thermal comfort in two modified rooms, namely the Department of Architecture Universitas Muhammadiyah Jakarta (UMJ) Building Technology Laboratory (Room A) and the Architecture Student Community "Fathirista" Room (Room B). Both rooms have similar microclimate factors (humidity, temperature, radiation and air velocity) were distinguished as one of the room was modified with an additional void and indoor garden space, while another room would be only added indoor garden space. In the experimental process, four types of modification were applied to both rooms. 26 students, who were familiar with the indoor climate environment of the modified rooms, were then asked to experience the four thermal condition modifications and to describe them by completing a Likert scale questionaire as a subjective evaluation step. Through this semi-experimental research, the aim was to discover different levels of thermal comfort experience through a perceptional study as an interpretation of subjective evaluation. The second purpose was to establish whether voids and indoor gardens could significantly affect thermal comfort. The data were analysed with SPSS software, with the results showing that the modified rooms with a void and additional indoor plants (Room A) was the most comfortable room according to the respondents' subjective evaluation. Even though the respondents had experienced the same thermal environment for years, they had different subjective evaluations towards the four modified conditions.
\end{abstract}

Keywords: Healthy house; Indoor garden; Sustainable architecture; Thermal comfort; Void

\section{INTRODUCTION}

Lechner (2007) claimed that thermal comfort is state of mind that reflects satisfaction with a building's thermal environment, which is affected by microclimate change surrounding it. Microclimate variables that affect comfort levels inside a building are air temperature (T), humidity (Ah, Sh, Rh), solar radiation and air velocity (V) (Lippsmeier, 1997). Understanding the environment and how to optimally utilize renewable resources such as wind, rainfall and sunlight is a future paradigm that we must prioritize in order to achieve thermal comfort, which clearly affects the level of human satisfaction.

\footnotetext{
*Corresponding author's email: anggana.fitri@ftumj.ac.id, Tel. +62-1-4256024, Fax. +62-1-4256023 Permalink/DOI: https://doi.org/10.14716/ijtech.v9i7.2638
} 
As stated in ANSI/ASHRAE Standard 55 which later be revised by De Dear \& Brager (2002), subjective human evaluation is important in asssessing thermal comfort, because results can only be meaningful by interpreting the condition of a person's mind that expresses satisfaction with the thermal environment. Thermal neutrality is maintained when the heat generated by the human metabolism is allowed to dissipate, thus maintaining thermal equilibrium with the surroundings.

Bakar et al. (2011) states that several aspects must be considered in sustainable housing development. Aside from non-physical aspects, such as social issues, economics and communication, there are also physical aspects that may affect housing sustainability, including the environment in general, site/land use, transportation and the assessment of building forms for housing performance. Baker evaluated various sustainable rating systems in order to find the best one for housing in Malaysia in particular. His research emphasized that to have a healthier and more sustainable built environment, we must enhance the physical aspect quality of buildings, in which thermal comfort is included. Wong and Khoo (2003) analyzed the thermal comfort of a classroom in Singapore using the ASHRAE scale, Bedford scale, votes of preference and direct votes of acceptability in order to investigate occupants' perceptions. Their research found that the classroom occupants generally accepted cool thermal sensations more readily than warm ones. They showed that the acceptable temperature range was from $27.1^{\circ} \mathrm{C}$ to $29.3^{\circ} \mathrm{C}$, implying that the ASHRAE standard of 55-92 was not applicable in the free-running buildings in the local climate. However, they did not suggest any solutions to improve the indoor thermal quality in the classroom.

Expectations and perceptions of thermal comfort can be affected by hot and humid environmental conditions throughout the year and by personal adaptation (Feriadi \& Wong, 2004). This is also supported by Humphreys et al. (2007) and Nikolopoulou and Steemers (2003), who state that thermal comfort is based on the context of people's lives, because individuals who are accustomed to living in climates in different spaces will have different thermal comfort perceptions. Satwikasari (2018) confirmed that physical factors of the house can affect the occupant's health state. She combined the perceptional study to measured the health quality of the occupants who suffered from Tuberculosis (TB) and also did field measurement to evaluated the thermal environment of their houses.

It is necessary for the room temperature to be averaged over a sufficient period of time, so that it can represent the usual conditions that people experience in their accommodation. The psychological dimension of thermal adaptation refers to an altered perception of, and reaction to, sensory information due to past experience and expectations. When the indoor thermal level of a building moves towards an uncomfortable level, people tend to take active strategies, such as turning on the air conditioning (AC), taking off clothes or opening windows. The greater the number of active strategies taken by the occupants, the higher the corresponding significant increase in energy consumption. To minimise energy consumption and to prevent deterioration of indoor thermal quality, passive designs have been chosen by researcher and architect in general as the best strategy to increase the quality of each thermal environment variable.

One of the most common passive design strategies in a low rise building is a void. This is basically an empty space located in between the upper and lower floors. It usually serves as a air circulation regulator, so that the temperature and natural light intake of a building can be maintained. Adding a hole in the upper floor allows occupants to let more air flow naturally inside the building from any air inlet in the top level of the building. A void also gives more chance for the occupants to adjust the local air quantity they need in order to balance their body temperature. Moreover, the existence of voids is very important to support the comfort and health of a building, especially for buildings that are close to their neighbours, because the hole 
of the void can also act as a wind tower, draining the hot air up, and giving a perfect crossventilation effect inside the building. Besides voids, another strategy to increase indoor air and thermal quality is to create an indoor green space. By adding indoor plants, oxygen availability inside a building can be increased. Aside from filtering dust within $3 \mathrm{~km}$ of dust sources, more than $75 \%$ of dust can be filtered by dense vegetation. Indoor plants can also reduces heat, as they serve as shade, and cool the room from the effects of direct solar UV and radiation. Klemm et al. (2015) suggests that adding more green space could be perceived as a better thermal environment.

Voids and indoor gardens were chosen by our team as the main modification aspects, as they can be two practical and affordable solutions for small to low-rise residential buildings. The funds needed to renovate an upper floor area with voids and to add indoor plants are considered to be quite low compared to the purchase of mechanical equipment for artificial ventilation, such as air conditioners, fans or exhaust fans. Furthermore, the addition of vertical air holes can also be a solution for a low-rise houses located in dense residential areas, which do not have residual land next to them. Therefore, an experiment with both passive design strategies is urgently needed in order to convince the community about the function of both voids and indoor gardens.

Prior research related to this semi-experimental project by Hakim $(2015 ; 2009)$ analysed the measured data with ANOVA methods for each thermal comfort variable, namely temperature $(\mathrm{T})$, absolute humidity $(\mathrm{AH})$, relative humidity $(\mathrm{Rh})$, air velocity (v), and Bedford Comfort Level (S), in the case of the existence of a void. However, the results showed that only $\mathrm{AH}, \mathrm{Rh}$, $\mathrm{v}$ and $\mathrm{S}$ were significantly influenced by the existence of the void. These results were confirmed by the DMRT (Duncan Multiple Ranges Test) method, especially the significant differences in air velocity (v) in both modified rooms.

In this advanced research, a perceptional study was conducted to measure the personal thermal comfort by employing a Likert scale questionnaire, with a scale derived from Bedford Comfort Levels (S), with selected respondents, with analysis using SPSS software to observe the percentage of each comfort level. By stabilizing the indoor air and temperature with the addition of void and indoor gardens, we aim to discover different thermal comfort experiences through a perceptional study as an interpretation of subjective evaluation. The second purpose is to prove whether voids and indoor gardens, as passive design strategies, can significantly affect thermal comfort quality in low-rise residential buildings. The paper will explain the assessment process and results of the thermal experiences in the modified experiment rooms with four different conditions.

\section{METHODS}

\subsection{Location and Research Periods}

This semi-experimental research was conducted in two rooms with the same microclimate factors located on the $3^{\text {rd }}$ Floor of the Department of Architecture Faculty of Engineering building in Central Jakarta (Figure 1). It was conducted during sunny weather between December 2014 and January 2015. 


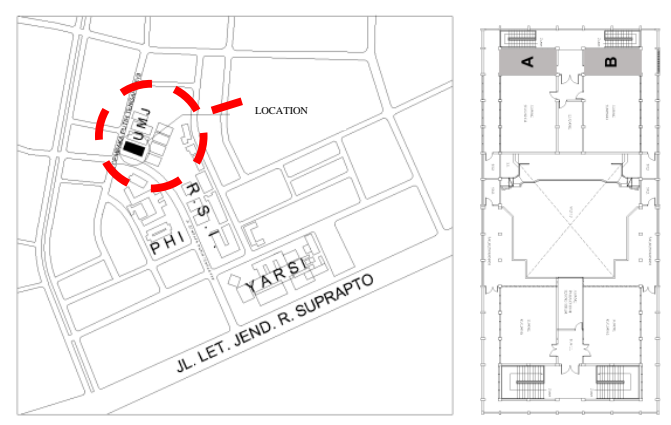

Figure 1 (Left) Location of the research; (Right) Floor plan of the $3^{\text {rd }}$ floor of the Department of Architecture, Universitas Muhammadiyah Jakarta (UMJ)

\subsection{Research Tools and Materials}

The tools used in the research were: (1) an anemometer to measure the air velocity (v); (2) a thermometer and hygrometer to measure the temperature (T) and relative humidity (RH); (3) SPSS as the quantitative analysis software to calculate the obtained results; and (4) a Likert scale questionnaire, together with other supporting equipment such as cameras and stationery. Additional material included a drawing book to create the spatial plan, and other supporting documents.

\subsection{Measurement Methods}

The research used the purposive sampling method, as the modification type had been determined, and the respondents who indicated their user perceptions on the Likert scale thermal quality questionnaire were 26 students from the Architecture Student Community, known as FATHIRISTA. Four types of modification were applied in the chosen rooms, which were the Department of Architecture Universitas Muhammadiyah Jakarta (UMJ) Building Technology Laboratory (Room A), and the Architectural Student Community (Room B).

In Room A, the modifications were V1IG0 (with void; without indoor garden) and V1IG1 (with void; with indoor garden), while in room B, the modifications were V0IG0 (without void; without indoor garden) and V0IG1 (without void; with indoor garden). V refers to 'void', IG refers to 'indoor garden', and the number following signifies existence of these if ' 1 ', and nonexistence if ' 0 '. Both rooms were of the same size and had the same level of ventilation, such as doors, bouvenlights and windows. This indicates that both rooms had the same air velocity (V), temperature $(\mathrm{T})$ and relative humidity $(\mathrm{Rh})$.

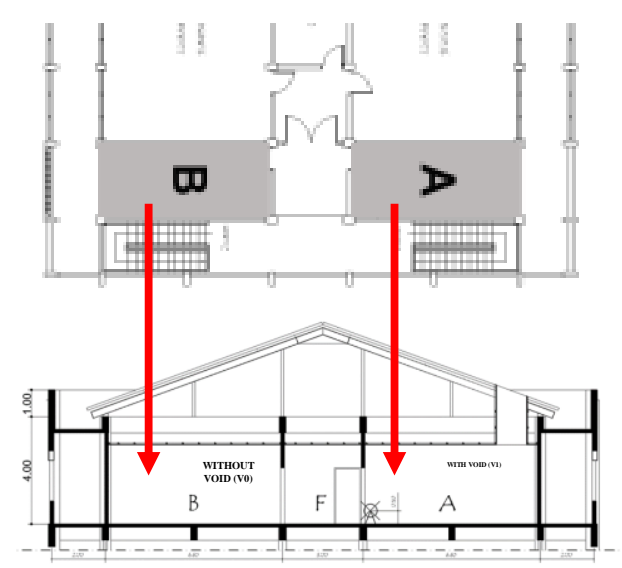

Figure 2 Floor section of the $3^{\text {rd }}$ floor of the Department of Architecture, Universitas Muhammadiyah Jakarta (UMJ) 


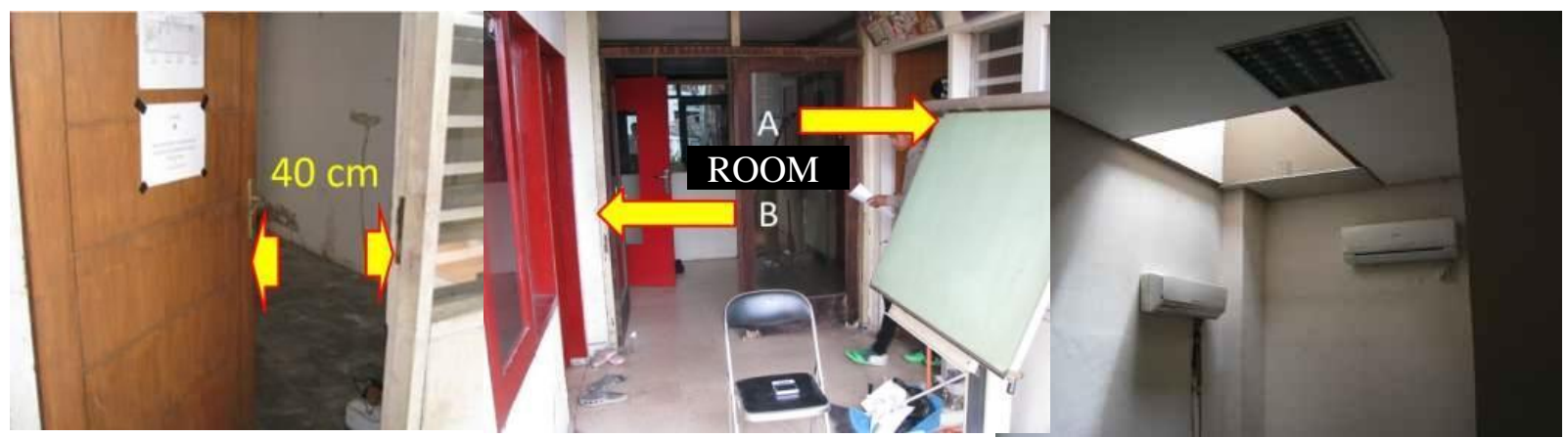

Figure 3 (Left) Door opening distance for each modified room to maintain the existing air velocity (v) from outdoors; (Center) Corridor outside the modified rooms; (Right) additional void built into room A

\subsection{Selected Respondents}

When the two modified rooms were ready, Likert scale questionnaires were distributed to the respondents, who were second year students of the Department of Architecture UMJ and who usually occupied and had activities in both experimental rooms throughout the year. They were assumed to be accustomed to the microclimate in the building and to have similar thermal experiences. The total number of participants was 26, comprising 13 males and 13 females.

\subsection{Analytical Methods}

A gradual analytical process was conducted in order to obtain appropriate results in line with the main purpose. Since the aim was to measure the perceptual opinions of the selected respondents about the modified rooms, the first analysis was based on Bedford thermal comfort standards (S). Anova analysis was then conducted to check the relationship between the thermal comfort variables, and the research concluded with a Likert scale questionaire which was interpreted by the seven Bedford comfort standards.

\section{RESULTS AND DISCUSSION}

\subsection{Thermal Data Measurement Process}

The thermal data in both rooms were measured twice, first on 10 December 2014 and then on 10 January, 2015. Each sample was taken at least three times, with intervals of 5 to 10 minutes, to obtain the average. Daily data collection was made at the peak of air temperatures, from 12.00 to 15.00 WIB (West Indonesia Time), since the building received maximum solar radiation during the two hours after 12.00 WIB, until 14.00 WIB. By assuming that the room would begin to feel uncomfortable during that time, the role of the wind as a factor would play an important role in the thermal comfort evaluation.

The anemometer was placed in the center of the open door at a height of $50 \mathrm{~cm}$ from the floor, according to the standard Bedford provisions. The thermometer was placed in the center of the space, along with a mark at which the respondents could record their thermal experience. 

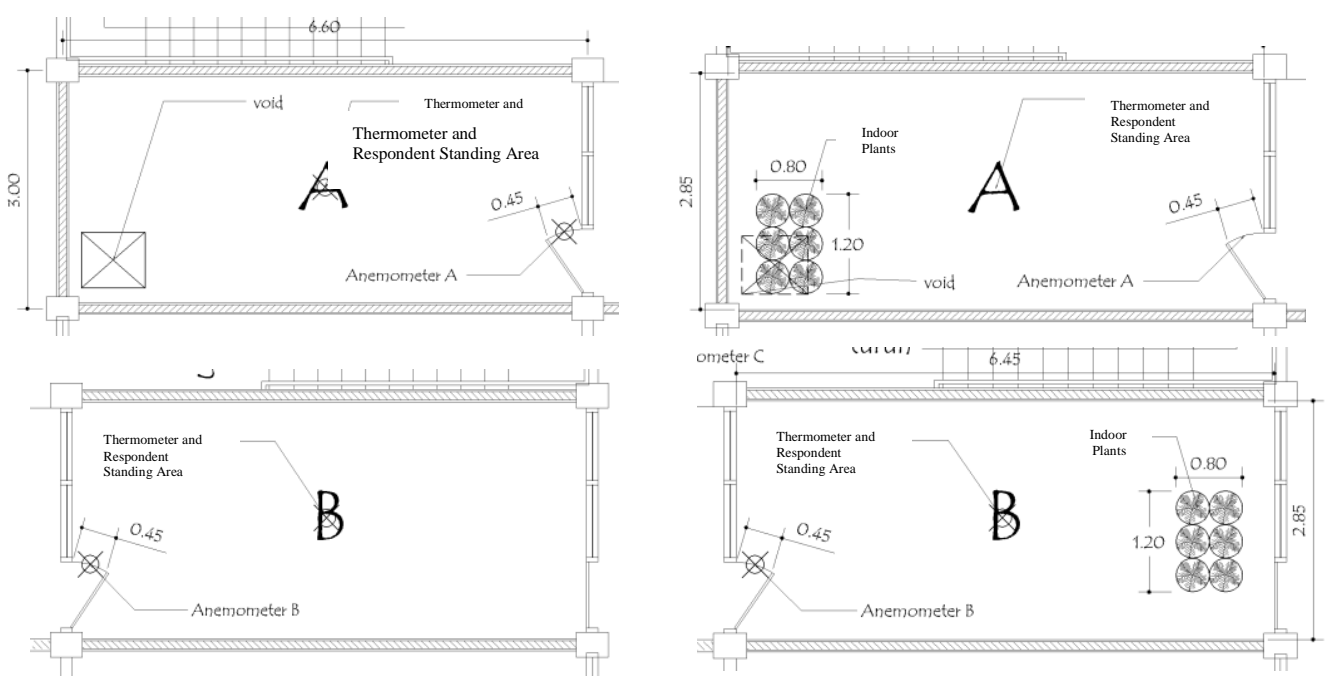

Figure 4 Floor plan of the two measured rooms, with four types of modification

As explained in section 2.3, in Room A the modifications were V1IG0 (with void; without indoor garden) and V1IG1 (with void, with indoor garden), while in room B, the modifications were V0IG0 (without void; without indoor garden) and V0IG1 (without void, with indoor garden). V refers to 'void', IG refers to 'indoor garden', and the number following signifies existence of these if ' 1 ', and non-existence if ' 0 '.

Both rooms had the same size and shape, at approximately $19 \mathrm{sqm}$. As can be seen in Figure 3 (right) and Figure 4 (V1IG1 and V1IG0), a hole was made at the back of the room. This was a minimal simulation of an ideal void that could be made in the floor area. It had a size of $80 \mathrm{~cm}$ $\times 70 \mathrm{~cm}$, or about $3 \%$ of the experimental floor space. The indoor plants were then placed at the back of the room as a simulation of an indoor garden. The plant canopy size was $80 \mathrm{~cm} \times 120$ $\mathrm{cm}$, or approximately $5.2 \%$ of the experimental floor area.

\subsection{Air Flow Direction}

During the data retrieval, observations were also made of the direction of the air flow that occurred. These showed that the air flows from the open space (corridor) between space A and B towards room A went directly across the void, as shown in Figure 5. It is concluded that the cross-ventilation process occurred in room A since it had the void, which acted as an additional outlet aside from the original open door or window. Static air pressure decreased when the temperature rose, and vice versa; since the air pressure in room A was higher than the air pressure around the void, the air flowed into the void and was replaced by air from the corridor.

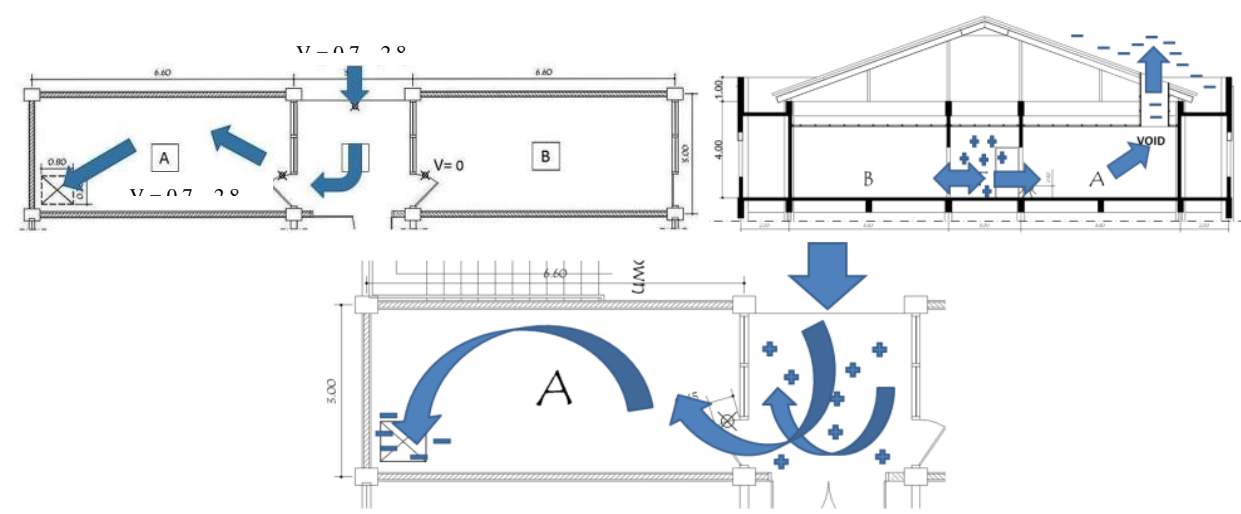

Figure 5 Illustration of the horizontal and vertical air flow direction, from the corridor to inside room A 


\subsection{Analytical Proccess}

\subsubsection{Bedford thermal comfort standard}

Bedford thermal comfort (S) needed to be analyzed first in order to make the Anova analysis. In the Bedford comfort formulae, absolute humidity (AH) must be measured, whereas the thermal data in the table was relative humidity $(\mathrm{RH})$, so it was first necessary to conduct data conversion. By using psychometric charts, the absolute humidity (AH) values were obtained by calculating room temperature $(\mathrm{T})$, relative humidity $(\mathrm{RH})$ and vapor pressure (vp). A summary of the measurements is given below.

1. (S) V0IG0; room temperature (T) was recorded at an average of $31.5^{\circ} \mathrm{C}, \mathrm{v}=0 \mathrm{~m} / \mathrm{s}$, and $\mathrm{RH}$ $=60.9 \%$, with comfort level at an average of 29.2.

2. (S) V0IG1; room temperature (T) recorded at an average of $31.6^{\circ} \mathrm{C}, \mathrm{v}=0 \mathrm{~m} / \mathrm{s}$, and $\mathrm{RH}$ $60.1 \%$, with comfort level at an average of 29.3.

3. (S) V1IG0; room temperature (T) recorded at an average of $31.6^{\circ} \mathrm{C}, \mathrm{v}=1.9 \mathrm{~m} / \mathrm{s}$ and $\mathrm{RH}$ $54.8 \%$, with comfort level at an average of 28.2 .

4. (S) V1IG1; room temperature (T) recorded at an average of $32.0^{\circ} \mathrm{C}, \mathrm{v}=1.6 \mathrm{~m} / \mathrm{s}$, and $\mathrm{RH}$ $566 \%$, with comfort level at an average of 28.2 .

These scores show that the Bedford thermal comfort $(\mathrm{S})$ for experimental room B without a void (V0) was 29.25, while for room A, with a void (V1), the score was 28.2. Based on the same analysis, Bedford thermal comfort (S) for V0IG1 was 0.1 points higher than for V0IG0. This indicates that the existence of an indoor garden (IG) in a room without a void (V0) affected the thermal comfort. However, in the room with a void, the score of (S) did not differ, although it was the best overall score (the lower the score, the better the comfort level). In conclusion, Bedford thermal comfort (S) will be better in a room with a void than in one without a void and indoor garden.

\subsubsection{Anova analysis to observe the relationship between thermal variables and additional modifications}

To determine the interaction between the physical factors of a room with a void and indoor garden, the physical thermal comfort factors ( $\mathrm{RH}, \mathrm{T}, \mathrm{V}$, and $\mathrm{S}$ ) were analyzed using Anova bivariate analysis. The results in Table 1 show that the void variable has a very significant relationship at $\alpha=0.01$ to air velocity (V) and Bedford thermal comfort (S). It means, the void presence in room A might affect to air velocity rate and impact on Bedford thermal comfort measurement result. However, the void didn't significantly relate to absolute humidity (AH) and room temperature $(\mathrm{T})$. The cross ventilation that occured from the door and window as air inlets which were going up to the void as air outlet, didn't stabilize the AH and didn't decrease the $\mathrm{T}$ since the room still get high solar radiation from the wall and roof. According to the same results, the presence of a void (V1) has a significant effect on increasing thermal comfort in a room, while the garden (IG1), which only comprises regular size plant, didn't show any relationship with thermal comfort.

Table 1 Anova analysis results

\begin{tabular}{|c|c|c|c|}
\hline Parameter & Void (V) & Indoor garden (IG) & Relationship between void and indoor garden \\
\hline Temperature (T) & tn & $\operatorname{tn}$ & $\operatorname{tn}$ \\
\hline Relative Humidity (RH) & $(*)$ & tn & tn \\
\hline Absolute Humidity (AH) & $\operatorname{tn}$ & $\operatorname{tn}$ & $\operatorname{tn}$ \\
\hline Air Velocity (V) & $(* *)$ & tn & tn \\
\hline Bedford Thermal Comfort (S) & $(* *)$ & $\operatorname{tn}$ & tn \\
\hline
\end{tabular}

Note; $(\mathrm{tn})$ : the relationship is not significant, $\alpha=0.05 ;(*)$ : less significant, $\alpha=0.02-0.04 ;(* *)$ : significant, $\alpha=0.01$ 


\subsubsection{Perceptional analysis as a subjective measurement of thermal comfort}

In this advanced step, a perceptional study was conducted by asking the 26 students to entered the four modified situations in the two measured rooms (Table 2). The respondents filled in the questionnaire with regard to the seven Bedford comfort levels.

Table 2 Bedford comfort levels of respondents in the four modified situations in the two measurement rooms

\begin{tabular}{|c|c|c|c|c|c|c|c|c|c|}
\hline Perception & $(\mathrm{S})$ & $\begin{array}{c}\text { V0IG0 } \\
\text { Number of } \\
\text { Respondents }\end{array}$ & $\%$ & $\begin{array}{c}\text { V0IG1 } \\
\text { Number of } \\
\text { Respondents }\end{array}$ & $\%$ & $\begin{array}{c}\text { V1IG0 } \\
\text { Number of } \\
\text { Respondents }\end{array}$ & $\%$ & $\begin{array}{c}\text { V1IG1 } \\
\text { Number of } \\
\text { Respondents }\end{array}$ & $\%$ \\
\hline Too Hot & 3 & 5.0 & 19.2 & 1.0 & 3.9 & & & & \\
\hline Hot & 2 & 12.0 & 46.2 & 9.0 & 34.6 & 3.0 & 11.5 & 1.0 & 3.9 \\
\hline Warm & 1 & 9.0 & 34.6 & 13.0 & 50.0 & 4.0 & 15.4 & 3.0 & 11.5 \\
\hline Normal & 0 & & & 3.0 & 11.5 & 7.0 & 27.0 & 4.0 & 15.4 \\
\hline Cool & -1 & & & & & 9.0 & 34.6 & 13.0 & 50.0 \\
\hline Cold & -2 & & & & & 3.0 & 11.5 & 5.0 & 19.2 \\
\hline Very Cold & -3 & & & & & & & & \\
\hline Total & & 26.0 & 100.0 & 26.0 & 100.0 & 26.0 & 100.0 & 26.0 & 100.0 \\
\hline
\end{tabular}

According to table 2, the values in red show the highest perception scores of each modification type. For example, in V0IG0 12 respondents, or $46.2 \%$ of the total, stated that the room was 'hot', whereas $50 \%$ of the respondents had a 'cool' sensation in V1IG1. The interpretation of the perceptional study using Bedford's seven thermal comfort levels is summarised in an easyto-read form in Figure 6.

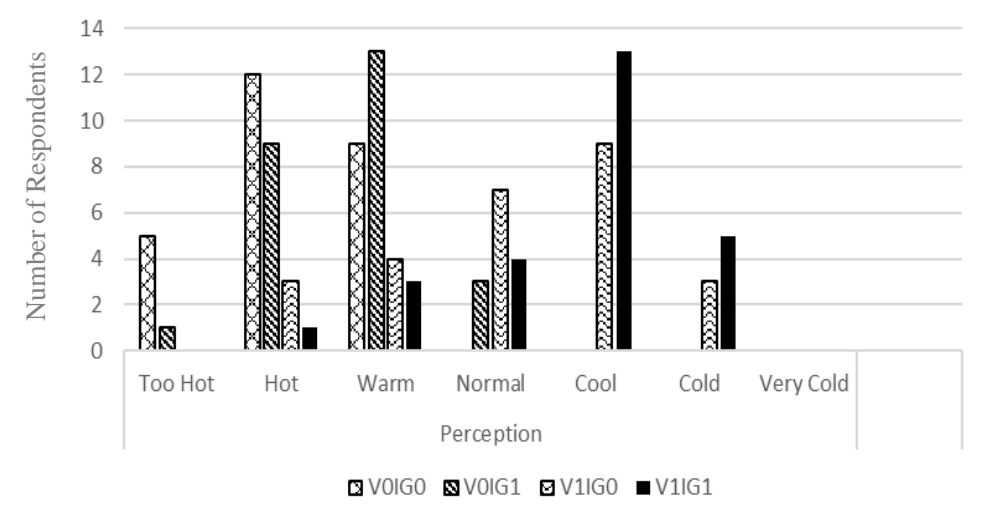

Figure 6 Perception evaluation of the 26 students in the four modified rooms

As can be seen in Figure 6, the respondents who entered the V0IG0 room only felt 'warm', 'hot' and 'too hot' sensations during the research periods. They said that the room was very uncomfortable and wanted to go out from it as soon as possible. In the room with the additional indoor plants (V0IG1), three people felt that the heat had been reduced, since they could feel that the room had been shaded by the plants and they said the comfort level, or their perception, of the room was 'normal'.

Another good sign was seen in the results of room V1IG0. No one said that the room was 'too hot' anymore; three participants even felt the room was 'cold' and wanted to stay longer since the room was becoming more comfortable, even though it had no indoor plants. This could be because cross-ventilation had been created through the void and window. Meanwhile, in the room with V1IG1 conditions, the respondents felt five kinds of comfort level, and almost 50\% of them said the room was 'cool'. 


\section{CONCLUSION}

On analysis of the results, the participants felt more comfortable in a room with an additional void, inicating the 'cool' or 'cold' options on the questionnaire. This shows that 'cool' or 'cold' sensations had become the standard comfort level for the respondents in the research. This means that by adding a void and installing some indoor plants below the void area, can successfully create the best thermal experience. Even though the respondents were accustomed to a certain microclimate in the modified rooms, they felt different individual thermal sensations. This might be because they had different thermal comfort tolerance levels, depending on their activities or daily life outside the building. This fact adds a new finding to the previous statement about perceptual opinions regarding thermal comfort. Subjective evaluation was not only affected by the quality of ventilation design to improve the comfort level, but also the context of individual life, which may affect sensitivity levels to changing conditions.

Through this experiment, there is strong evidence that by adding an appropriate void inside a narrow and dark room, especially in low-rise buildings, it is possible to effectively increase indoor thermal quality. By adding an 'additional hole' above, an additional air outlet is also created, resulting in cross-ventilation. With faster air velocity (V) inside a room, relative humidity (RH) will move towards its ideal percentage, thus also increasing the Bedford Thermal Standard (S) point. Moreover, indoor plants will add more green space inside a building, which could improve the oxygen banks and subsequently occupants' health.

Suggestions for further research include finding the ideal void area percentage to floor area, as this can affect the Floor-Area-Ratio (FAR). Voids can also be an effective alternative passive design for the dense settlements in urban areas, as vertical ventilation helps building occupants to get more natural ventilation and lighting. Hopefully, this research will initiate more projects related to healthy and green built environments by optimising passive strategies.

\section{ACKNOWLEDGEMENT}

We would like to thank LPPM Universitas Muhammdiyah Jakarta (UMJ), which provided research funding, the Department of Architecture UMJ, and also the Faculty of Engineering UMJ, for giving us chance to conduct this research and use their facilities.

\section{REFERENCES}

Bakar, A.H.A., Cheen, K.S., Rahmawaty, 2011. Sustainable Housing Practices in Malaysian Housing Development : Towards Establishing Sustainability Index. International Journal of Technology, Volume 2(1), pp. 84-93

De Dear, R.J., Brager, G.S., 2002. Thermal Comfort in Naturally Ventilated Buildings: Revisions to ASHRAE Standard 55. Energy and Buildings Journal, Volume 34(6), pp. 549-561

Feriadi, H., Wong, N.H., 2004. Thermal comfort for naturally ventilated houses in Indonesia. Energy and Buildings Journal, Volume 36(7), pp. 614-626

Hakim, L., 2009. Pengudaraan Silang Pada Pengembangan Rumah Sederhana (Cross-airing on Simple House Development). NALARs, Volume 8(1), pp. 1-19

Hakim, L., 2015. Efektifitas Void Pada Pengudaraan Silang Untuk Kenyamanan Di Dalam Ruang (Void Effectiveness in Cross-airing for Comfort in Indoor Space). Jurnal Arsitektur NALARs, Volume 14(2), pp. 131-144

Humphreys, M.A., Nicol, J.F., Raja, I.A., 2007. Field Studies of Indoor Thermal Comfort and the Progress of the Adaptive Approach. Advances in Building Energy Research, Volume 1(1), pp. 55-88 
Klemm, W., Heusinkveld, B.G., Lenzholzer, S., Jacobs, M.H., Hoved, B.V., 2015. Psychological and Physical Impact of Urban Green Spaces on Outdoor Thermal Comfort during Summertime in the Netherlands. Building and Environment, Volume 83, pp. 120 128

Lechner, N., 2007. Heating Cooling Lighting Metode Desain untuk Arsitektur. Jakarta (ID): PT. Raja Grafindo Persada

Lippsmeier, G., 1997. Bangunan Tropis. Jakarta (ID): Erlangga.

Nikolopoulou, M., Steemers, K., 2003. Thermal Comfort and Psychological Adaptation as a Guide for Designing Urban Spaces. Energy and Buildings, Volume 35(1), pp. 95-101

Satwikasari, A.F., 2018. Exploratory Study of Physical Environment Factors Affecting Tuberculosis Endemics Houses in Kebumen District, Indonesia. International Journal of Built Environment and Scientific Research, Volume 02(1), pp. 65-74

Wong, N.H., Khoo, S.S., 2003. Thermal Comfort in Classrooms in the Tropics. Energy and Buildings, Volume 35(4), pp. 337-351 